\title{
8
}
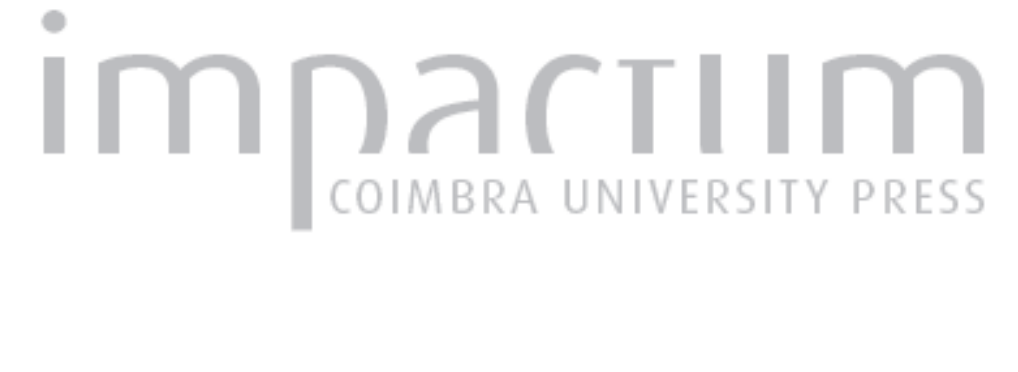

Dos juizados especiais criminais à justiça restaurativa: a "justiça consensual" no
Brasil

Autor(es): $\quad$ Souza, Luanna Tomaz; Fabeni, Lorena Santiago

Publicado por: Universidade Católica de Petrópolis

URL persistente:

URl:http://hdl.handle.net/10316.2/33706

DOI:

DOI:http://dx.doi.org/10.14195/2175-0947_5-1_8

Accessed : $\quad$ 26-Apr-2023 05:27:58

A navegação consulta e descarregamento dos títulos inseridos nas Bibliotecas Digitais UC Digitalis, UC Pombalina e UC Impactum, pressupõem a aceitação plena e sem reservas dos Termos e Condições de Uso destas Bibliotecas Digitais, disponíveis em https://digitalis.uc.pt/pt-pt/termos.

Conforme exposto nos referidos Termos e Condições de Uso, o descarregamento de títulos de acesso restrito requer uma licença válida de autorização devendo o utilizador aceder ao(s) documento(s) a partir de um endereço de IP da instituição detentora da supramencionada licença.

Ao utilizador é apenas permitido o descarregamento para uso pessoal, pelo que o emprego do(s) título(s) descarregado(s) para outro fim, designadamente comercial, carece de autorização do respetivo autor ou editor da obra.

Na medida em que todas as obras da UC Digitalis se encontram protegidas pelo Código do Direito de Autor e Direitos Conexos e demais legislação aplicável, toda a cópia, parcial ou total, deste documento, nos casos em que é legalmente admitida, deverá conter ou fazer-se acompanhar por este aviso.

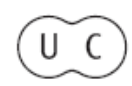



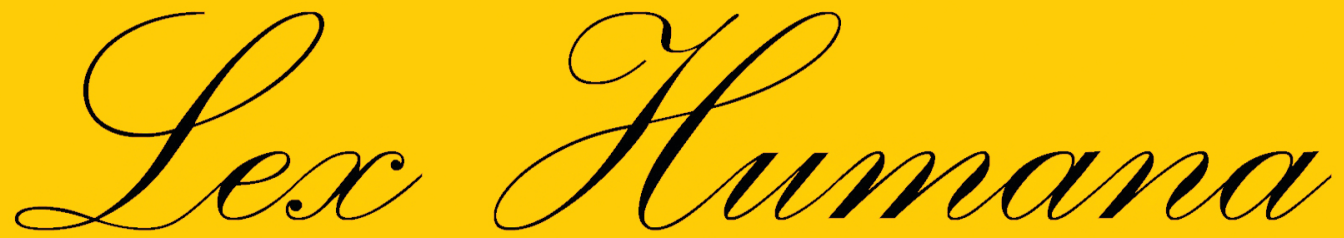

Revista do Programa de Pós-Graduação em Direito da UCP

ISSN(e) 2175-0947

Universidade Católica de Petrópolis Rua Benjamin Constant, 213 - Petrópolis - Centro CEP 25610-130

Tel: (24) 2244-4000 E-mail: lexhumana@ucp.br 


\title{
DOS JUIZADOS ESPECIAIS CRIMINAIS À JUSTIÇA RESTAURATIVA: A “JUSTIÇA CONSENSUAL" NO BRASIL
}

\section{SPECIAL CRIMINAL COURTS TO RESTORATIVE JUSTICE: THE CONSENSUAL JUSTICE IN BRAZIL*}

\author{
LUANNA TOMAZ SOUZA** \\ UNIVERSIDADE FEDERAL DO PARÁ, BRASIL \\ LORENA SANTLAGO FABENI*** \\ UNIVERSIDADE FEDERAL DO PARA, BRASIL
}

\begin{abstract}
Resumo: Os problemas que o sistema penal enfrenta cada vez mais se mostram visíveis. $O$ presente artigo analisa o surgimento dos Juizados Especiais Criminais como uma alternativa penal e sua proposta de Justiça Consensual. Ressaltam-se numa perspectiva crítica, os limites deste e o advento da Justiça Restaurativa como uma nova perspectiva teórica.
\end{abstract}

Palavras-chave: Juizados Especiais Criminais; justiça restaurativa; justiça consensual.

Abstract: The problems facing the criminal justice system increasingly visible show. This article analyzes the emergence of Special Criminal Courts as an alternative to criminal justice and its proposed Consensual. It is emphasized, a critical perspective, this limits the advent of restorative justice as a new theoretical perspective.

Keywords: Special Criminal Courts; restorative justice; justice consensual.

\section{Introdução}

O direito e o sistema judicial têm sofrido nas últimas décadas profundas modificações que variam em cada sociedade em função do seu desenvolvimento econômico e social, da cultura jurídica, das transformações políticas e do padrão de litigação decorrente do tipo de utilizadores dos tribunais judiciais e da relação entre a procura potencial e efetiva da resolução de um litígio.

\footnotetext{
* Artigo recebido em 17/02/2013 e aprovado para publicação pelo Conselho Editorial em 26/04/2013.

** Professora da Universidade Federal do Pará, Brasil. Doutoranda em Direito pela Universidade de Coimbra, Portugal. Currículo lattes: http://lattes.cnpq.br/5883415348673630. E-mail: luannatomaz@ufpa.br.

*** Professora da Universidade Federal do Pará, Brasil. Doutoranda em Direito pela Universidade Federal do Pará, Brasil. Currículo lattes: http://lattes.cnpq.br/8479788871403626. E-mail: $\underline{\text { lfabeni@msn.com. }}$
} 
Diante disto, apontam-se simultaneamente diversos caminhos. Por um lado, a expansão do direito, com a chegada de "novos" litígios oriundos da sociedade ou do mercado ao tribunal. Por outro lado, desenvolve-se uma tendência para desjudicialização dos conflitos, buscando-se formas de resolução dos mesmos: alternativas (ou seja, são criadas formas de concorrência com os tribunais), complementares (atuando diante da demanda que não vai aos tribunais) ou mesmo substitutivas (como em alguns casos de divórcio que sequer vão aos tribunais) ao Poder Judiciário.

No Brasil, os Juizados Especiais Criminais, criados a partir da Lei n 9.099/95 são a principal expressão deste movimento, carregando o discurso de uma justiça mais célere, mais informal, mais eficiente na prestação jurisdicional. Entretanto, a realidade dos juizados tem revelado nuances que necessitam ser perquiridas, levando-nos a suscitar inúmeras questões, como quais são as demandas que efetivamente são julgadas nestes espaços e até que ponto a estrutura judicial e pessoal criada é adequada para resolução destas ou mesmo se realmente podemos falar da criação de uma justiça consensual no Brasil.

\section{O Processo como mecanismo de resolução de conflitos}

Ao viver em sociedade, buscando a realização de seus ideais de vida e proporcionando proteção às suas prerrogativas naturais, o ser humano defronta-se cotidianamente com diversos conflitos de interesses, sejam eles, individuais, coletivos ou difusos. O conflito, contudo, não pode ser considerado um mal em si mesmo, pois têm funções individuais e sociais importantes, proporcionando o estímulo para as mudanças e o desenvolvimento individual. Todavia, a sociedade deve prover sua população de modos de solucionar seus conflitos, exercendo seus direitos e deduzindo suas pretensões. No decorrer dos séculos, a humanidade continuamente se preocupou com a criação e o aperfeiçoamento dos meios de pacificação dos conflitos.

Passamos pelo momento onde prevalecia a auto-tutela, que se caracteriza pelo fato de que uma das partes impõe o sacrifício do interesse da outra. Ela expressa um sentimento de vingança, como na Lei da XII Tábuas, originária da Lei do Talião - olho por olho, dente por dente, em que se limitava a vingança ao tamanho do dano. Este modelo foi gradativamente substituído pela auto composição, que estabelecia um ressarcimento à vítima, unilateral ou bilateralmente, total ou parcialmente.

O processo nasce no momento em que a composição da lide passa a ser função estatal, surgindo a jurisdição em sua feição clássica, ou seja, o poder-dever dos juízes de dizer o direito na composição das pendências, sendo o processo seu método. 
Não foi, contudo, extinta a possibilidade de resolução de conflitos através da designação de um árbitro ou através de outros mecanismos para além da jurisdição estatal. Todavia, principalmente no âmbito penal, a vítima sai do foco de atenção ocorrendo a chamada "expropriação do conflito" pelo Estado, sendo a vítima neutralizada passando a ser mera informadora do delito.

Hodiernamente as soluções dos conflitos se realizam às custas da intervenção estatal materializada na decisão judicial, dotada de coerção típica da atuação soberana do Estado, ou à margem de qualquer atividade estatal como ocorre nos meios alternativos de solução de conflitos.

O recurso aos tribunais enquanto instância de resolução de conflitos ocorre num campo de alternativas várias de resolução, de tal modo que por vezes o tribunal de primeira instância é acionado após terem falhados outros meios de resolução de conflitos, tais como a família, a Igreja, o centro comunitário, o partido político.

Em que pese a crescente demanda pela via judiciária, aberta a porta do Tribunal, contudo, a intensidade do uso deste ainda assim pode variar bastante. É crescente o movimento de criação de meios alternativos de resolução de conflitos, esses são expressão do novo paradigma de desjudicialização, que alguns países têm sofrido, diante da ineficácia dos tribunais.

Isso ocorre principalmente pela ineficiência na prestação do Estado, e diversos fatores contribuem para isto. A morosidade no julgamento dos processos, o pensamento arcaico, a ineficiência e a desordem na condução dos processos, fomentando o desprestígio da administração da justiça, que gera a insatisfação e descrédito dos jurisdicionados.

Para o êxito da utilização do processo como meio de alcançar a justiça há custos que devem ser levados em consideração como o custo econômico, social e psicológico da transação; a conformidade mútua das partes com o resultado, ou seja, a satisfação dos interesses e a crença em um resultado justo; o efeito produzido na solução da relação entre as partes; e por fim a reincidência do conflito, ou seja, a durabilidade da pacificação das partes e a possibilidade de que se reitere o conflito no futuro.

As medidas que se vem desenvolvendo visam facilitar o acesso à justiça, tanto fora como durante os processos judiciais, e desenvolver procedimentos complementares dos processos jurisdicionais, estando estes muitas vezes melhor adaptados à natureza dos litígios.

O poder judicial assume em muitos lugares a função de promotor dos meios alternativos. Em vários países, são os juízes que aconselham ou impõem o recurso prévio a formas de resolução alternativa dos litígios. Os modelos consensuais de resolução de conflitos têm-se propagado como alternativa aos modos clássicos de confrontação. Promove-se assim uma justiça negociada, de consenso e reparadora. Para Filho (2008) são de ordem consensual a autocomposição e a 
heterocomposição, pautadas numa perspectiva negociada, não adversarial, onde as partes mantêm o controle sobre o procedimento e a decisão final. Configuraria, em sentido oposto, uma ordem imposta, a autotutela e a heterocomposição, quando expressa a imposição de um terceiro alheio a vontade das partes, mediante ato de autoridade e poder.

Em realidade, todo esse processo está relacionado às próprias transformações do Estado. Os Tribunais são um dos pilares fundadores do Estado constitucional moderno. Boaventura de Sousa Santos (1996) identifica três períodos marcantes que mostram uma evolução nessa relação: o Estado Liberal, o Estado providência e a crise do Estado providência. O próprio autor ressalta que essa trajetória histórica não se adequa aos países periféricos e semi-periféricos, pois quando do Estado Liberal, muitos destes ainda eram colônias e o Estado Providência é fenômeno político exclusivo dos países centrais.

Nesses países, que passaram por processos de transição democrática nas últimas três décadas, os Tribunais só muito lenta e fragmentariamente têm assumido maior participação política na atuação providencial do Estado. Entretanto, boa parte, desses países experimentou uma explosão de litigação com o aumento no significado sócio-político dos tribunais e o reconhecimento de novos direitos. Esse aumento no padrão de litigação varia em cada país de acordo com o desenvolvimento socioeconômico e a cultura jurídica. Pedroso (2006) divide em fatores exógenos e endógenos aqueles que interferem no movimento processual. Os primeiros dizem respeito às transformações sociais, econômicas, políticas e culturais e ao seu impacto na administração da justiça. Os fatores endógenos consistem nas alterações legislativas, institucionais e técnicas.

Varia também de país para país a capacidade de adaptação da oferta judicial à procura judicial. Em regra está acompanhada de reformas voltadas a informalização da justiça; o reapetrechamento dos tribunais com recursos humanos e informatização; reformas processuais; e, a criação de tribunais especiais para a pequena litigação de massa.

Quanto a esse último aspecto, foco deste artigo, é necessário ressaltar que o surgimento dos Juizados Especiais Criminais (JECrim) deu espaço no sistema judiciário para demandas de violência do cotidiano, que antes ou não eram trazidas para o sistema, ou terminavam sendo "engavetadas" nas delegacias num controle arbitrário por parte dos delegados e delegadas que evitavam que estes conflitos "ocupassem” os tribunais, por serem "brigas de vizinho", "brigas de marido e mulher", "mal-entendidos", sendo banalizadas.

Tal realidade influencia os padrões de litigação, conceito que tem sido utilizado para dar conta do modo como são geridas socialmente as relações litigiosas numa dada sociedade, sendo exemplificada através de uma pirâmide onde a ponta é representada por aquelas demandas que 
chegam aos Tribunais. De fato, um comportamento lesivo de uma norma não é suficiente para desencadear o litígio, em boa parte os/as lesados/lesadas sequer se dão conta do dano ou de que podem reagir. Segundo Santos (1996: 45), "os grupos sociais têm percepções diferentes das situações de litígio e níveis de tolerância diferentes perante as injustiças em que elas se traduzem.” Por isso, baixo nível de litigiosidade não significa que haja poucos conflitos. Os grupos de maior vulnerabilidade têm mais dificuldade de transformar a lesão em litígio.

Esse artigo chama atenção justamente para os obstáculos impostos a esses grupos, pois os mesmos têm dificuldade na percepção dos danos sofridos e quando esta é alcançada tem lugar, principalmente com o aumento na consciência de direitos que o Brasil tem sentido e com o surgimento do JECrims, não se permite que seja transformada em efetivo alcance da justiça.

\section{Habermas e a justiça consensuada}

As principais correntes do pensamento político contemporâneo conferem centralidade ao papel do direito e da cidadania na construção de um Estado democrático. Um pensador importante para o assunto é Habermas, para quem o direito, ancorado na moral e não mais na racionalidade instrumental-cognitiva da ciência, é o elemento estruturador da democracia.

Habermas cumpre um papel importante na atualidade ao estabelecer uma contundente crítica ao positivismo, pois, segundo ele, somente através da crítica, compreendida como autoreflexão e autoquestionamento, é que os momentos reprimidos, ocultos, distorcidos pelo processo histórico do conhecimento, podem ser recuperados, reelaborados e conscientizados, permitindo redescobrir os interesses fundamentais, o da emancipação (FREITAG e ROUANET, 1980).

Em "Lógica das Ciências" reconstituiu a história da reflexão metodológica sobre as ciências humanas, mostrando como as insuficiências do empirismo puro vão dando lugar a tipos de reflexão, como a hermenêutica, de Gadamer, que tentam substituir o enfoque objetivante, pelo qual o cientista social se situa como um observador neutro diante de seu objeto, pelo Verstehen, a compreensão, que supõe a imersão do intérprete em seu objeto, que ele consegue captar, na medida em que dela participa.

Assim como a crítica ao positivismo constitui o fio vermelho que ultrapassa todos os trabalhos de cunho epistemológico, a crítica ao Estado e à sociedade é o fio condutor dos estudos que, de uma perspectiva político-cultural, procuram elucidar a relação de teoria e prática.

Em “As mudanças estruturais do espaço público”, ressalta o espaço público como aquela instância na qual se forma a opinião, que tinha no início funções críticas com relação ao Poder, e mais tarde foi refuncionalizada para canalizar o assentimento dos governados. Dentro dessa 
perspectiva político-cultural adquirem maior peso os trabalhos sobre o Estado e as modernas formas de legitimação adotadas pela sua variante tecnocrática.

Toda ideologia formada, tanto pelo Estado liberal quanto pelo Estado capitalista, aparece com a função de impedir a tematização dos fundamentos do poder. A ideologia tecnocrática ${ }^{1}$ distingue-se das demais porque é a única que visa impedir a problematização do poder, não através da legitimação das normas, mas através de sua supressão: o poder não é legítimo por obedecer a normas legítimas, mas por obedecer a regras técnicas, das quais não se exigem que sejam justas, e sim, eficazes.

Ela nega assim a própria estrutura da ação comunicativa, a assimilando à ação instrumental. Enquanto a ideologia liberal se baseia numa intersubjetividade fundada em normas, que precisam ser justificadas, esta se baseia em regras que não necessitam de qualquer justificação. Assim, o que está em jogo é a tentativa de sabotar a própria estrutura de interesses da espécie, que inclui, ao lado do interesse instrumental também o interesse comunicativo. Como resultado, as decisões práticas que afetam a coletividade são agora transformadas em problemas técnicos, resolvidos por uma minoria de experts, que têm o know-how necessário, impondo uma despolitização das massas (FREITAG e ROUANET, 1980).

Ambas as críticas realizadas por Habermas, da cultura e do conhecimento, tem parentescos evidentes. Em um ou outro caso, trata-se de trazer à tona momentos reprimidos ${ }^{2} \mathrm{e}$ contribuir para revelar não somente a interpenetração da falsa teoria e da falsa práxis (positivismo e capitalismo tardio) como a interpenetração da teoria e da práxis. Essa vinculação vai ser conceitualizada numa teoria da competência comunicativa.

Ao descrever a comunicação linguística, Habermas ressalta que em cada situação de fala, existem quatro "expectativas de validade": a de que os conteúdos transmitidos são compreensíveis; a de que os interlocutores sejam verazes; a de que os conteúdos proposicionais sejam verdadeiros; e a de o locutor, ao praticar o ato linguístico em questão, tenha razões válidas para fazê-lo, isto é, aja conforme normas que lhe pareçam justificadas. A interação espontânea é estável quando existe um consenso com relação a essas quatro expectativas de validade, e é perturbada quando uma delas é contestada de forma fundamental, gerando uma comunicação distorcida.

\footnotetext{
${ }^{1}$ Pautada na ciência e na tecnologia, controladas, manipuladas e promovidas pelos Estados para ser ele mesmo o "promotor" do progresso e do bem-estar coletivo.

${ }^{2}$ De um lado, a auto compreensão objetivista da ciência, reprime a estrutura de interesses que condiciona a objetividade dos seus enunciados; de outro, a autocompreensão tecnocrática do poder, reprime o substrato político de ações praticadas em nome de uma racionalidade técnica.
} 
As duas primeiras podem ser problematizadas e resolvidas no próprio contexto da interação, contudo, a problematização do conteúdo proposicional e da norma subjacente ao comportamento só pode ocorrer fora do contexto interativo, numa forma de comunicação que Habermas chama de discurso. No discurso, ficam postos de fora os interesses e motivos característicos da interação normal, sendo o único motivo admitido: a busca cooperativa da verdade, à base do melhor argumento. A afirmação problematizada é debatida num discurso teórico enquanto a norma, problematizada é debatida num discurso prático.

Para Habermas, numa situação linguística ideal, todos os interessados podem participar do discurso, todos têm oportunidades idênticas de argumentar, dentro dos sistemas conceituais existentes ou transcendendo-os, e todos têm chances simétricas de fazer e refutar afirmações, interpretações e recomendações ${ }^{3}$.

O poder, assim, apenas é legítimo quando resulta de um consenso. É o consenso universal dos integrantes de um discurso, no caso prático, que fundamenta a validade das normas e instituições, conferindo-lhes legitimidade. O consenso perfeito, contudo, somente pode ser alcançado quando as instituições que canalizam e asseguram a comunicação já estiverem liberadas de seus momentos repressivos, num contexto livre de violência e coação. Nas sociedades modernas, entretanto, as instituições impedem a formação de um consenso livre: constituem barreiras externas à comunicação desinibida.

Habermas rejeita, nesse sentido, a perspectiva de uma justiça do ponto de vista do proveito distributivo, onde um juiz, em seu papel ideal de um observador imparcial, realiza uma generalização imparcial da vantagem de cada um dos afetados e "distribui a justiça". Para ele, uma prática ou regulação só pode considerar-se válida se puder encontrar o assentimento dos próprios afetados, ainda, sob condições de discussão que obriguem a todos os participantes a adotar também a perspectiva de cada um dos outros. Somente da perspectiva de uma intersubjetividade de ordem superior, que não corta o acesso ao saber intuitivo dos participantes nem prejulga as posturas de assentimento ou negação pode julgar-se imparcialmente se algo resulta bom para todos por igual. Deste modo, não será alguém aplicando a justiça, mas os próprios afetados praticando-a (HABERMAS, 1996).

Tais reflexões de Habermas são fundamentais para desnudar uma justiça que se propõe consensuada, mas que cria inúmeras barreiras para o acesso dos indivíduos a justiça. Com a promessa de resolver disputas por meio da comunicação e do entendimento, e permitindo uma intervenção menos coercitiva e mais dialógica, em um espaço estrutural que antes ficava à margem

\footnotetext{
${ }^{3}$ Essas seriam as duas condições que configurariam o modelo da ação comunicativa pura: uma forma de interação (e de organização social) caracterizada pela eliminação de todas as formas de coação externa e interna.
} 
a prestação estatal de justiça, a informalização da justiça penal pode ser um caminho para o restabelecimento do diálogo, contribuindo para reverter a tendência de dissolução dos laços de sociabilidade no mundo contemporâneo, mas precisa superar seus limites refletindo sobre suas bases estruturais e a forma com que se realiza no cotidiano.

\section{O contexto de surgimento dos Juizados}

O Juiz, em que pese o discurso positivista de neutralidade, cada vez mostra-se mais distante da realidade das partes litigantes, aplicando um direito oficial muitas vezes desconexo com os anseios sociais, não satisfazendo ou acalmando empiricamente as partes que sentem nas decisões judiciais a injustiça, a intolerância, a impunidade, a frustração. Os Juízes são assim considerados por boa parte da população como conservadores, insensíveis e distantes da contextura social, cada vez mais complexa, na qual se desenvolve o conflito. Também crescem as críticas aos modelos de "expropriação dos conflitos", reivindicando-se maior participação da vítima no processo decisório.

Diante da insatisfação, o modelo de justiça, na qual o Estado tem o monopólio da jurisdição e da elaboração das normas jurídicas cada vez mais tem sido questionado, assumindo as vestes de um modelo de direito dogmático e impositivo. Ganha corpo, assim, a tendência de buscar as soluções dos conflitos de um modo menos traumático, sempre tentando a composição das partes, de forma amigável e com base na realidade social que informa a pendência existente ${ }^{4}$.

Estas formas de resolução buscam resolver o conflito com base numa maior interação entre as partes, além disso, representam a procura por uma resolução de conflitos que prescinde as normas estatais, ou seja, a redução do direito à mera forma legislada (legal), com aplicação restrita por parte do Judiciário para solução das contendas ${ }^{5}$. São utilizadas muitas vezes as normas previstas e prescritas por cada segmento específico, respeitando apenas o núcleo mínimo de direitos e garantias estabelecidas nas Constituições e Cartas Fundamentais de cada Estado.

Em tese, ao Judiciário apenas seriam levadas as questões mais intrincadas e que exigissem uma análise tópica de dispositivos legais, tais como questões de controle de constitucionalidade

\footnotetext{
${ }^{4}$ Além das mediações comumente realizadas entre as partes fora do âmbito judicial, tem se valorizado cada vez mais: as conciliações, a arbitragem, as comissões prévias de resolução de conflitos.

${ }^{5}$ Em que pese o exposto, boa parte dos agentes do direito ainda se apoia numa visão do direito enquanto fenômeno restrito à lei, sem perceber as contradições existentes em nosso atual sistema jurídico em relação aos princípios que exprime ou para que deveria tender; sem por a nu as dissonâncias menos visíveis e desvelar os pontos em que a pretensa racionalidade do sistema é afinal a expressão de interesses espúrios e não de qualquer exigência superior. (ASCENSÃO, 1994).
} 
das leis. Além disto, o Estado e o Judiciário também serviriam para conter abusos de poder na composição dos litígios.

Os Juizados Especiais Criminais no Brasil vão surgir como contraponto ao processo penal tradicional, que cada vez mais é apresentado como insuficiente. Este, segundo Araújo (2003), baseia-se no princípio da nulla poena sine judicio, segundo o qual o Estado deve exercer unicamente duas funções: acusar e julgar. Com o tempo, contudo, experiências trágicas ensinaram a que catástrofes a exacerbação da tendência a dar ênfase unilateral aos interesses do Estado, minimizando a posição das partes, podia conduzir. A isso veio somar-se forte e generalizada inclinação a reputar errônea a insistência numa política criminal assente sobre a premissa de que o poder público não pode deixar de levar até o derradeiro impulso a persecução de todo aquele a quem se atribua a prática de infração penal.

Para Andrade (1996), o sistema penal tradicional legitima-se a partir de dois polos básicos, que retratam as promessas preconizadas pelo discurso oficial: a legitimação tradicional pela legalidade e a legitimação pela utilidade. O caminho da legalidade apresenta o sistema penal como um exercício racional e programado do poder punitivo do Estado, limitado estritamente pelos termos da Lei e pelos princípios básicos do Estado de Direito, do Direito Penal e do Processual Penal.

Além da legalidade, que encerra as exigências formais do sistema, também são consideradas as funções de utilidade social da pena, que supostamente funcionaria como "retribuição" (equitativa e justa) ante o cometimento de ato punível e como "prevenção" (geral e especial) do crime. O sistema penal cumpriria assim funções específicas sempre delimitadas pelos ditames da lei: a defesa dos bens jurídicos socialmente relevantes e o combate ao crime. O apelo legitimador desse "duplo eixo" subsiste até os dias de hoje.

$\mathrm{Na}$ realidade, medeia o sistema uma lógica estrutural de operacionalização que viola os princípios constitucionais e os fins declarados no Direito Penal, cumprindo uma função diametralmente oposta. Desta feita, ao invés de combater e eliminar a criminalidade, o sistema cada vez mais a produz e controla seletivamente (HERMANN, 2004).

A atuação dos agentes do sistema toma como base formal precípua a lei penal, que constrói uma programação simultaneamente ambígua, na medida em que tipifica condutas humanas de forma hipotética deixando abertos espaços subjetivos para a construção interpretativa do aplicador do texto legal. Esses agentes realizam uma seletividade muitas vezes inconsciente que estabelece variáveis diversas, como estereótipos, sem contar a ação inconsciente de todo um universo de preconceitos, concepções e ideias, construídos ao longo de sua vida pessoal. Isso implica reconhecer no sistema penal uma crise de legitimidade, que contabiliza uma população 
carcerária de homens negros, pobres e sem instrução, com altos índices de reincidência e, tendo as condutas contra o patrimônio como principal criminalidade combatida, o que revela valores sociais dominantes e emergentes.

Em se tratando da pena de prisão, historicamente precedida por penas corporais essencialmente desumanas, ela foi por muito tempo vista como uma evolução do exercício do direito de punir, o que de fato não corresponde a realidade. A pena de prisão aparta o indivíduo de seu mundo, privando-o do direito de ir e vir, ao mesmo tempo em que o insere num universo aparte de relações deturpadas e de negatividade. Essas mazelas implicam um sofrimento moral, espiritual e psicológico que é estéril. Além disso, a pena de prisão é um castigo corporal, representado pelas privações do cárcere que se intensificam diante da deficitária capacidade operacional do sistema, como as más condições físicas dos estabelecimentos prisionais, a falta de recursos humanos adequadamente treinados e a falta de recursos materiais que propiciem uma "condição humana digna" ao segregado.

A prisão não é um instrumento hábil para promover a ressocialização de ninguém, na medida em que reflete as desigualdades sociais e segrega os indivíduos excluídos pela própria sociedade, que ainda acompanhará os indivíduos apenados até depois do cumprimento da pena. Sem contar os efeitos do isolamento da pena sobre sua família, aquilo que se convencionou chamar de transferência da pena, tendo em vista que o encarcerado é habitualmente arrimo de família. Esta acaba penalizada economicamente, socialmente e psicologicamente.

Os problemas que o sistema penal enfrenta cada vez mais se mostram visíveis: o excesso de leis; a fragmentação e o isolamento dos diversos organismos componentes do sistema; o despreparo dos agentes nos serviços policiais, judiciais e penitenciários; a sobrecarga dos tribunais, que redunda em delonga na prestação jurisdicional; a ineficácia das penas e inexistência de tratamentos produtivos, somados a resistência às inovações, com claro apego aos sistemas tradicionais criminalizantes.

Para Wunderlich (2005), em que pese a relevância da crítica que delimita empírica e cientificamente o sistema penal estatal como um sistema injusto, repressivo, estigmatizante e seletivo, não se pode olvidar que a partir do momento em que o Estado avoca o direito de punir, é estabelecido um avanço no sentido do distanciamento da vítima do conflito em que ela estava inserida. Afastá-la do conflito, para o autor, foi prudente, além de representar o início da erradicação da vingança privada e para a concretização da proporcionalidade da sanção pelo desvio praticado. Todavia, o autor ressalta que, quer se queira ou não, os efeitos nefastos da vingança privada ainda estão bem presentes na justiça criminal brasileira, especialmente representados pela 
ideologia repressivista da tolerância zero adotada pela prefeitura de Nova York nos anos 90 e defendida por setores do espectro político.

Nesse sentido, o autor advoga pela necessidade de se estabelecer critérios de racionalidade e civilidade à intervenção penal, deslegitimando qualquer modelo de controle social maniqueísta que coloca a 'defesa social' acima dos direitos e garantias individuais. Para que esses critérios de racionalidade e civilidade sejam (realmente) implantados seria necessário um processo penal justo por intermédio de um devido processo que buscasse a eticização da conduta do Estado enquanto ocupado na prevenção e repressão de condutas desviantes. Isso, os Juizados Especiais Criminais não irão representar.

\section{A criação dos Juizados Especiais Criminais}

O processo de criação dos Juizados Especiais tem início a partir de 1980, com os Conselhos de Conciliação e Arbitragem, experiência pioneira dos juízes do Rio Grande do Sul. Tais órgãos não tinham função judicante, sendo uma experiência que obteve altos índices de conciliação.

Em 1984, houve a edição da Lei Federal n ${ }^{\circ} 7.244$, que estabelecia os Juizados de Pequenas Causas para julgamento de causas de reduzido valor econômico (até 20 salários mínimos). Estes se espalharam por todo o país com alta demanda, em que pese a estrutura precária, a carência material e de pessoal. A Constituição de 1988 chegou a determinar a criação dos Juizados Especiais Cíveis e Criminais. Como o legislador federal não apresentava regulamentação para a matéria, alguns Estados passaram a entender, com esteio no artigo 24, incisos X e XI da Constituição Federal, que teriam competência legislativa concorrente, sendo criados Juizados no Estado de Santa Catarina e no Mato Grosso. Como o Supremo Tribunal Federal decidiu que os Estados não poderiam legislar foram propostos vários projetos na Câmara Federal ${ }^{6}$.

A Lei $\mathrm{n}^{\circ}$ 9.099/95 regulamenta os Juizados Especiais Criminais e insere as figuras da conciliação ou composição e da transação penal ${ }^{7}$ na dinâmica dos juizados de pequenas causas e impõe um novo padrão processual, voltado para o exame da criminalidade derivada das infrações

\footnotetext{
${ }^{6}$ Habeas corpus no 71713-6, da Paraíba, em 26 de outubro de 1994.

${ }^{7}$ Há no juizado uma fase de conciliação ou composição, onde há a possibilidade de acordo entre as partes, em seguida há a fase da transação penal, onde cabe ao Ministério Público propor a aplicação imediata da pena de multa ou de alguma pena restritiva de direito (chamada comumente de pena alternativa), como: a limitação de fim de semana, a prestação de serviços à comunidade, bem como as penas de prestação pecuniária, nos termos do Art. 76 da Lei ${ }^{\circ} 9.099 / 95$.
} 
penais conceituadas como de menor potencial ofensivo, atendendo às questões judiciais penais que exigiam maior presteza da resposta do Poder Judiciário sem prejuízo da segurança da prestação jurisdicional.

A existência dos Juizados Especiais Criminais pressupõe a moderna conceituação de institutos da ação e do processo penais, necessária à compatibilização da proporcionalidade da atividade policial, ministerial e judicial, com o bem jurídico violado e definido no direito material. De acordo com o pensamento de inúmeros processualistas brasileiros, o JECrim coloca em curso um dos mais avançados programas de despenalização do mundo, trazendo profundas transformações doutrinárias para o sistema penal, como a transformação da infração penal em delito civil, disciplinarização de determinadas condutas e a resposta médica e terapêutica como forma de administrar conflitos.

O sentido que orientou a criação dos juizados é o do consensualismo nas questões judiciais pelos critérios da oralidade, simplicidade e informalidade, celeridade e economia processual, buscando consumar, num primeiro momento, a conciliação, a composição cível, através de um acordo negociado que pode resultar, inclusive, em uma indenização pecuniária à vítima pelo autor do fato, o que configura uma "civilização" do processo penal.

Caso a composição não seja possível ou ainda no caso de crimes de ação penal pública incondicionada, passa-se, em um segundo momento, para a transação penal ou suspensão condicional do processo, priorizando interesses como a reparação dos danos sofridos pela vítima e a aplicação de pena alternativa, não-privativa de liberdade, normalmente na forma de prestação de serviços à comunidade ou doação de mercadorias de utilidade para instituições filantrópicas.

A conciliação no Processo Penal brasileiro, todavia, não é novidade inaugurada pela Lei n ${ }^{\circ}$ 9.099/95. O Código de Processo Penal de 1941 trazia essa possibilidade no processo e no julgamento dos crimes de calúnia e injúria (art. 519 a 523). Nestes casos, antes do recebimento da queixa, as partes são chamadas a comparecer em juízo para uma audiência de conciliação, que ocorre na presença somente do magistrado e das partes, desacompanhadas de seus defensores. Sendo possível a reconciliação, ocorre automaticamente a desistência da queixa, com o seu consequente arquivamento.

Esta conciliação é marcadamente extraprocessual, papel que até então era relegado somente ao Delegado/Delegada de Polícia, com vistas a não deixar entrar no sistema, casos que considera não necessitarem de qualquer apreciação judicial, muitas vezes, chamando as partes a sentarem a sua frente e discutir a questão. Até hoje boa parte das demandas das delegacias sequer configuram crimes, mas apenas ensejam a atuação da polícia para intimidar uma das partes ou promover uma espécie de acordo. 
De fato, a conciliação como medida oficial era instituto, até então, pouco utilizado no Direito Processual Penal, que agora passa a ter grande abrangência em função da nova Lei dos Juizados. E a Lei $n^{\circ}$ 9.099/95 trouxe novos institutos, que abririam portas para práticas de despenalização, contudo, a prática não superou as expectativas que a Lei gerou. Houve um momento inicial de euforia, com uma divulgação insensata e acrítica da 'novidade', representada, o que gerou uma idolatria ao novo. Isto serviu para mais do que refletir a realidade, buscar na tradição do discurso jurídico brasileiro, conformar esta própria realidade, conferindo sentido supostamente unívoco ao que a prática jurídica revela ambíguo, polêmico e controvertido. (WUNDERLICH, 2005).

A ideia inicial seria de que diante do sistema penal tradicional e das catástrofes por ele geradas, aos processos de "pequena gravidade" seria favorecida uma solução consensual, capaz de abreviar o processo, atenuar a sobrecarga de trabalho dos órgãos judiciais e até impedir, em certa medida, o contínuo agravamento do sério problema de superlotação carcerária (ARAÚJO, 2003). Sustentava-se que às primeiras não se justificaria um processo demorado, pois, solucionadas de maneira rápida, por via conciliativa, sobraria tempo para os órgãos da persecução penal poderem se dedicar com maior eficácia as questões de maior repercussão.

Contudo, as limitações da lei começaram no tratamento linear que impôs às chamadas "infrações de menor potencial ofensivo" ${ }^{8}$, definidas a partir do quantum da pena em abstrato imposta ao tipo. Este critério reafirmou a seletividade do sistema penal, pois as penas mais pesadas do Código Penal, com exceção do homicídio, são arbitradas aos delitos contra o patrimônio.

Nos juizados especiais então passaram a ser julgados casos de violência racial, conjugal, contra o idoso, e outras onde a grande maioria dos casos termina com medidas despenalizadoras ignorando-se a potencialidade lesiva destes conflitos. Os crimes mais comuns nestes espaços são a lesão corporal, a ameaça e os crimes contra a honra e todo e qualquer crime cuja pena seja inferior a dois anos.

Nos casos de violência contra grupos vulneráveis, esse sistema não faz mais que duplicar as dores da vítima, expondo-as a um ritual indiferente e formal, que desconsidera a diversidade inerente à condição humana. Deflagra um aparato que não está munido de mecanismos necessários para a mediação do conflito, o que a leva a retirar-se do espaço público que conquistou

\footnotetext{
${ }^{8}$ A Lei n ${ }^{\circ}$ 9.099/95, em seu art. 61 considera como crimes de menor potencial ofensivo as contravenções penais e os crimes que a lei comine pena máxima não superior a um ano. Esta lei foi alterada pelo Lei ${ }^{\circ} 11.313$, de 28 de junho de 2006, que determina nova redação do art. 61: Consideram-se infrações penais de menor potencial ofensivo, para os efeitos desta Lei, as contravenções penais e os crimes a que a lei comine pena máxima não superior a 2 (dois) anos, cumulada ou não com multa.
} 
ao longo de uma história de lutas, para retornar à esfera do privado desmuniciada de qualquer resposta 9

Como a grande maioria dos casos é resolvida nas etapas de conciliação e transação temos que notar que o grande administrador dos conflitos é o/a conciliador/a. Essa figura surge na Lei 9.099/95 para prestigiar a ideia da participação da sociedade na administração da Justiça.

$\mathrm{O} / \mathrm{a}$ conciliador/a não exerce qualquer atividade jurisdicional. Segundo o parágrafo único do art. 73 da Lei dos Juizados, são auxiliares da Justiça, recrutados, na forma da lei local, preferentemente entre bacharéis em Direito, excluídos os/as que exerçam funções na administração da Justiça Criminal. Merece atenção a expressão "preferentemente", que deixa bem claro não ser imprescindível o grau acadêmico para o desempenho das funções.

O Judiciário deve aplicar os novos institutos de forma a obter o melhor retorno social, não podendo se ater a formalismos. Os comodismos devem ser abandonados de maneira que se alcancem os melhores resultados da atuação jurisdicional, eliminando dos horizontes da Justiça, formalidades e entraves que em nada ajudam na resolução do caso concreto.

Isso sem levar em contar a falta de capacitação desses/as conciliadores/as, em regra estudantes de direito. Na verdade, também é visível o despreparo dos/as juízes/as na mediação do conflito. Um/a bacharel em direito, via de regra, não tem qualquer formação conciliatória, nem transdisciplinar (psicológica, sociológica) capaz de lhes trazer um manancial teórico ou capacitálos para a mediação do conflito via processo de conciliação. Na realidade, invariavelmente, a formação do/a magistrado/a brasileiro/a é meramente técnico-jurídica, formalista e limitada à subsunção da lei ao caso penal. Um/a juiz/a é preparado/a para tomar decisões e não conciliar.

Em face da tradição monista e cartesiana que marca o sistema penal, a tendência é resistir a qualquer tipo de capacitação interdisciplinar, pois se acredita na especialização, o que resulta na perpetuação do quadro atual, de uma Justiça tecnicista, fria e indiferente aos dramas humanos que desfilam nos corredores dos fóruns e nas salas de audiência.

Além do problema acerca de quem realiza a conciliação, um dos pressupostos para uma "justiça consensuada" seria que as partes estivessem em posições de igualdade, capazes de tomar decisões acerca de seus interesses. Segundo Rodrigues (1998), a justiça negociada pode parecer a primeira vista, como a mais adequada para uma sociedade igualitária e complexa, que ao mesmo tempo questiona o Estado-providência e rejeita a colonização da vida cotidiana pelo direito. Contudo, a ideia de uma justiça negociada assenta-se, na realidade, numa ficção: a igualdade entre as partes.

${ }^{9}$ Ver HERMANN (2004). 
Diante de uma estrutura autoritária de processo como é de sua natureza a do processo penal, o ofensor encontra-se necessariamente numa posição de inferioridade em relação aos atores judiciários, cujo papel social que desempenham os coloca numa posição de superioridade. Longe de contribuírem para a igualdade das partes, os processos negociados reforçam a desigualdade. Isso ocorre, por exemplo, quando as partes estão desacompanhadas nas audiências, sem sequer compreender o que está sendo determinado. A ausência de advogados/as, a rapidez da audiência e a falta de um real processo conciliatório, não permite às partes o esclarecimento sobre as alternativas colocadas pela legislação para a resolução do litígio.

Os/as protagonistas do conflito precisam compreender o que está acontecendo, quem são as pessoas com quem estão conversando e o que estas pessoas estão dizendo. A própria linguagem formal, juridicizada, é absolutamente imprópria, porque confunde e atemoriza, e afasta a ideia de uma justiça acolhedora e paciente. Além disso, seria necessário um/a profissional que soubesse interagir com a vítima de modo a obter sua confiança e despertar nela sentimentos de segurança. Por isso é tão necessária, na Justiça a sensibilização dos agentes que estabelecem esse contato direto com a vítima. Entram em pauta, aí, questões relevantes como linguagem, ambiente, aproximação.

A esse tratamento indiferente e indiferenciado Hermann (2004) chama de trivialização do conflito. $\mathrm{O} /$ a legislador/a trata o conflito familiar como trataria qualquer outro tipo de conflito, desconsiderando os interesses da vítima e a necessidade de oferecer não apenas uma solução formal, tecnicamente adequada, mas antes de tudo uma trilha que possa conduzir à efetiva pacificação do conflito. Com essa expressão não se pretende eliminar o conflito, mas antes seu enfrentamento de forma tal que se torne administrável para seus protagonistas, especialmente para a vítima. A mira deve ser a solução para o conflito não para o processo. Por isso, a autora trabalha com a ideia de pacificação de conflito, não com o objetivo de eliminar os conflitos, mas de proporcionar instrumentais para que os/as protagonistas possam administrar a relação que vivenciam, colocando sob controle as diferenças que deflagraram a violência.

Como pensar deste modo, conforme preceitua Habermas em um consenso, onde todos os/as afetado/as têm oportunidades idênticas de argumentar, dentro dos sistemas conceituais existentes ou transcendendo-os, e têm chances simétricas de fazer e refutar afirmações, interpretações e recomendações? Afinal, a ideia de uma justiça consensuada seria permitir no espaço das audiências uma interação entre os/as protagonistas do conflito e os/as agentes do direito que permitisse um consenso. Há na realidade, uma comunicação deformada, com barreiras impostas pelo sistema judiciário. 
Além disso, há que se ter em conta a posição do/a acusado/a. Depois da vigência da Lei $\mathrm{n}^{\circ}$ 9.099/95, nos "crimes de menor potencial ofensivo", basta uma diligência na Delegacia de Polícia para que o/a autor/a do fato seja chamado ao Poder Judiciário. Em certos casos ele/a constitui defensor/a, comparece ao judiciário, pois é obrigado/a, mas na verdade houve um registro de uma ocorrência que narra um fato inexistente ou que não retrata a verdade. Isto ocorre porque não há qualquer investigação sobre o que foi narrado, o que Wunderlich (2005) chama de hipervalorização do Termo Circunstanciado.

$\mathrm{O} / \mathrm{a}$ autor/a da suposta infração acaba por aceitar qualquer benefício que lhe seja formulado em audiência a fim de evitar o risco de responder a um eventual processo. Soma-se a isso, o infortúnio de ter que fazer chamamento de testemunhas para demonstrar sua inocência, de ser constrangido a participar de audiências na condição de réu, de que outras pessoas de sua família ou trabalho percebam que esta sendo processado criminalmente, de ter que comunicar seu endereço em caso de alteração e, ainda, de ter que custear os honorários advocatícios (diante da deficiência da Defensoria Pública). Para o/a autor/a do fato acaba a pena restritiva de direitos para ele imposta, sendo menos gravosa que o custo do processo. A seletividade do sistema, antes exercida pela polícia, agora é colocada nas mãos do/a denunciante.

A Lei 11.340, de 22 de agosto de 2006, conhecida como Lei Maria da Penha, também nos trouxe uma importante lição ao afastar a aplicação dos Juizados Especiais nos casos de violência doméstica e familiar cometida contra a mulher. Isto se deu como resultado de uma luta histórica dos movimentos de mulheres diante das agruras na aplicação da Lei 9.0099/95 e mostrou à sociedade que nem tudo pode ser conciliado. Que determinadas situações exigem uma atenção especial, uma investigação adequada e um processo que respeite essas especificidades e não que trate o conflito como se fosse mais um.

\section{Justiça restaurativa como uma possibilidade?}

As sociedades pré-estatais, sobretudo as européias e as coletividades nativas, tinham como prática cotidiana dos seus regulamentos sociais a manutenção da coesão do grupo, ou seja, os interesses coletivos superavamos interesses individuais. A ruptura ou a transgressão da norma gerava reações orientadas para o restabelecimento ou a restauração do equilíbrio esgarçado pela conduta ilícita, buscando-se uma rápida solução para o problema. Nessas sociedades comunais a tendência era a utilização de mecanismos capazes de conter a desestabilização do grupo social, ainda que as formas punitivas de vingança ou morte não tenham sido abolidas. 
Os vestígios dessas práticas restaurativas remontam sua existência anterior a primeira era cristã a exemplo do Código de Hamurabi (1700 a.C.), Código de Lipit-Ishar (1875 a.C.), Código Sumeriano (2.050 a.C.) e o Código de Ashuma (1700 a.C.) e encontradas também entre os povos colonizados da África, Nova Zelândia, Áustria, América do Norte e do Sul, e também nas sociedades pré-estatais da Europa. Portanto, importa dizer que a justiça restaurativa surge nas sociedades comunais e pré-estatais que estão mais ligadas à estrutura social do que à cultura, ou seja, precede as práticas tradicionais dos povos nativos (JACCOULD, 2012).

Porém, as formas de justiça negociada foram reduzidas consideravelmente com o advento da centralização do poder e o nascimento do Estado e, nesta fase da formação do Estado, ocorre o afastamento da vítima no processo criminal.

Dando um salto social, o ressurgimento dos modelos retaurativos e os processos a ele associados foram encorajados por três correntes de pensamento: i. A primeira surge a partir da contestação das instituições repressivas através dos trabalhos da escola de Chicago e da Universidade de Berkley (Califórnia). Está sustentado pela ideia durkheimiana de que o conflito não é uma divergência da ordem social mas sim uma característica normal e universal das sociedades e neste sentido o movimento critica as instituições repressivas e o processo de definição do criminoso, reconhecendo portanto, a necessidade de uma justiça diferente, humanista e não punitiva ${ }^{10}$; ii. a descoberta da vítima, através dos estudos da Vitimologia, que inicialmente possui um viés positivista (porquanto reflete o pensamento da época) detendo-se em identificar os elementos que submetem os indivíduos a se tornarem vítimas também traz grande contribuição para o modelo restaurativo em que pese não ter participado diretamente do seu advento. Os estudos das consequências da vitimização despertam profunda sensibilidade dos teóricos do modelo retributivista, nomeadamente para a ausência da vitima no processo penal e suas necessidades; iii. A exaltação da comunidade, como terceiro eixo de pensamento, merece destaque como local em que situa a justiça restaurativa porquanto relembra as sociedades tradicionais onde a quantidade de conflitos é numerosa, porém melhor administrada prevalecendo a regra da negociação (JACCOULD, 2012).

A denominação justiça restaurativa é atribuída a Albert Eglash, psicólogo que, em 1977, escreveu um artigo intitulado Beyond Restitution: Creative Restitution (PINTO, 2007). O conceito atribuído toma como ponto de chegada a restituição criativa que está afeita à reabilitação técnica onde cada ofensor, sob supervisão adequada, é ajudado a encontrar algumas formas de pedir

\footnotetext{
${ }^{10} \mathrm{Na}$ Europa o eco desse movimento se verifica em Michel Foucault, Françoise Castel, Robert Castel e Anne Lovel, Nils Christie e Louk Hulsman.
} 
perdão a quem atingiu com sua ofensa e buscar uma nova oportunidade. Eglash defendeu que haviam três respostas ao crime - a retributiva, baseada na punição e/ou no castigo; a distributiva, focada na reeducação ou tratamento do ofensor; e a restaurativa ou recompensadora, cujo fundamento seria a reparação e/ou restituição.

A crítica que se faz a proposta de Eglash é que permanece focada na pessoa do ofensor dando pouca ou nenhuma visibilidade à vítima, limitando-se a reintegração social a satisfação material das consequências evento.

Nos anos 90, H. Zher publica Changing Lenses (Trocando as Lentes), livro paradigmático para a compreensão de justiça restaurativa rompendo com o modelo retributivo e, portanto, identificando a existência de dois modelos de justiça opostos, porém a nosso juízo não conflitantes, que é o modelo retributivo e o modelo restaurador. Logo em seguida, em 1993, L. Walgrave (1993) propõe que a justiça é marcada por três tipos principais de direito, a saber, o direito penal, o reabillitador e o restaurativo.

É relevante localizar a justiça restaurativa em relação ao direito penal e ao reabilitador, sobretudo porquanto ser o direito penal ramo duro do direito, nomeadamente porquanto atinge com mais intensidade o corpo social através da pena como resposta ao comportamento transgressor da norma.

O direito penal, portanto evolui em um estado opressor e elege o delito, a infração como ponto de partida para se manifestar buscando restabelecer o equilíbrio moral causado pelo mal através da aplicação de uma dor. Busca como objetivo a noção da justa pena ancorado no princípio da proporcionalidade e coloca a vítima em um local secundário. Ora veja, é compreensível que esta moldura social onde se exterioriza do direito penal fez sentido, ou, como queiram alguns, ainda o faça, em um dado contexto que não é o que se apresenta na contemporaneidade de sorte que estamos descortinando possibilidades várias de tratar do fenômeno criminal a partir das transformações da sociedade pelas quais vem passando não apenas no âmbito penal, mas também fora dele. A descentralização do poder do Estado, a desagregação do modelo de estado de bem estar social, a diferenciação e complexidade crescente das relações sociais, o simbolismo jurídico, o aparecimento de uma sociedade civil, a elevação do neoliberalismo e a fragmentação dos centros de decisões remodelaram profundamente as relações entre os cidadãos e o Estado (JACCOULD, 2012). E é neste contexto de profundas transformações que a justiça restaurativa vem se desenvolvendo e, portanto, em uma constante construção de aproximação conceitual, teórica e prática.

No que diz respeito ao direito reabilitador temos que se realiza em um Estado de providência que elege o agressor como ponto de partida e busca para ele tratamento com o 
objetivo de adaptá-lo às regras sociais e também localiza a vítima em um plano secundário. Portanto, também não nos parece que dê conta de fazer frente às demandas oriundas das transformações sociais que se delineiam ao longo do processo histórico. É possível que tenha significado algum avanço, mas devemos considerar como um direito que não altera substancialmente para melhor as relações sociais que estão construídas em novas bases, ou seja, na participação e na coadministração, tendo em vista que o Estado se liberou, em um certo sentido, de uma parte da administração e da segurança.

O direito restaurador se apresenta bem distante dos direitos acima delineados, porquanto elege o prejuízo causado como referência buscando eliminar o erro com a responsabilização dos danos causados e a consequente reparação destacando, portanto, o local da vítima como sendo o central. Toma como objetivo a satisfação dos envolvidos pelo crime de modo que o Estado responsabilize os envolvidos.

Deste modo podemos estão nos aproximar de um conceito de justiça restaurativa que minimamente dê conta de ser compreendido a partir do contexto social em que ela ressurge. Assim sendo compartilhamos alguns conceitos de alguns autores que frequentemente recorremos.

John Braithwhite (1999) a compreende como um processo onde se pretende trazer conjuntamente os indivíduos afetados por uma ofensa, (ou seja, por um crime) e onde se procura, com o seu acordo, saber como reparar os danos causados pelo crime. O objetivo desse processo consiste em restaurar as vítimas, os agentes do crime e a comunidade.

No Brasil, Renato Sócrates Gomes Pinto (2012), ainda que preliminarmente, entende que a justiça restaurativa, pode ser definida como um procedimento de consenso, em que a vítima e o infrator, e, quando apropriado, outras pessoas ou membros da comunidade afetados pelo crime, como sujeitos centrais, "participam coletiva e ativamente na construção de soluções para a restauração dos traumas e perdas causados pelo crime".

Porém, a aproximação conceitual mais apropriada e que compartilhamos é de Mylène Jaccourd (2012) que se posiciona dizendo que a justiça restaurativa é uma "aproximação que privilegia toda a forma de ação, individual ou coletiva, visando corrigir as consequências vivenciadas por ocasião de uma infração, a resolução de um conflito ou a reconciliação das partes ligadas a um conflito". Para construí-lo a autora revela três modelos de justiça restaurativa que partem de premissas diferentes, porém, não excludentes ou conflitantes.

Um modelo de reparo que adota as consequências como ponto de partida de sua ação, no qual a responsabilidade é mais única e utiliza a comunicação entre as partes (mediação) ou um processo de arbitragem como meio de atingir os objetivos reparadores. É um modelo centrado nas finalidades da justiça restaurativa; ii. um outro modelo de resolução de conflito, portanto 
centrado nos processos e, um iii. terceiro modelo de conciliação e reconciliação, pautado, portanto, nos processos e finalidades.

Ora bem, o modelo focado nas finalidades é visto por Walgrave (1993) como a perspectiva máxima da justiça restaurativa, porquanto está voltado para as consequências e cujas finalidades são centrais e prioritárias independentemente dos processos aplicados para atingi-los. Admite, portanto, à guisa de exemplo, a arbitragem como meio processual secundário para buscar suas finalidades. Neste modelo pode o juiz impor sanções restaurativas nas hipóteses em que uma das partes se recuse a participar do procedimento restaurativo, ou uma das partes é desconhecida ou morta.

O foco nas finalidades de fato é uma das alternativas mais próximas de conceber a justiça restaurativa como um modelo complementar ao modelo de justiça tradicional, como também é o modelo que favorece a restauração, no caso das vítimas mortas ou desconhecidas cujas família, parentes, vizinhança tiveram laços esgarçados pelas consequências do delito. Não há como vislumbrar, contudo, uma finalidade restaurativa com a ausência do ofensor ou mesmo seu desconhecimento, a uma porque o encontro há de ser consensuado livremente entre as partes; a dois porque quando da realização do encontro restaurativo não se discute autoria porquanto já está formada e conhecida; e a três porque o acordo restaurativo deve ser realizado pelo ofensor, portanto não ultrapassar sua pessoa tampouco substituída sua responsabilidade por outrem. Mas fica o desafio.

O modelo focado nos processos compreende a finalidade como secundária, e são os processos que definem o modelo de justiça restaurativa fundamentado na participação. Neste modelo as finalidades assumem traços retributivos, por outro lado, somente o fato de existirem as negociações, as consultas ou os envolvimentos é suficiente para que alguns considerem que suas práticas façam parte de um modelo de justiça restaurativa. Este modelo é o que mais corrompe os princípios fundamentes da justiça restaurativa porquanto uma justiça participativa ou comunitária somente é justiça restaurativa caso e apenas, se, as ações praticadas objetivarem a reparação das consequências do crime. Este modelo pode tudo fazer em termos de processo e atribuir a isso justiça restaurativa, inclusive adotar percursos de matriz retributiva mascarando-o de restaurativo.

O modelo focado nos processos e finalidades define a justiça restaurativa através de processos negociáveis e também através de finalidades restaurativas cujos critérios para encaminhamento dos casos para os programas restaurativos estão baseados no bom senso o que de certa feita conduz à administração de infrações sumárias reduzindo o potencial da ação da justiça restauradora. Ainda vemos com muita resistência a tomada de decisões pautadas nas 
emoções. Estamos atrelados a uma racionalidade que impede as manifestações emocionais, é inegável, todavia, que homens e mulheres geralmente cometem delitos motivados por emoções e sentimentos, muitas das vezes vis, que não são trabalhados, estimulados ou compreendidos.

Neste sentido Kay Pranis (2012) revela que ao longo de 16 anos trabalhando com a justiça restaurativa com os aborígenes do Canadá e os indígenas dos Estados Unidos aprendeu sobre a coragem de falar abertamente a respeito de assistência e perdão, sobre coragem de falar de coração aberto e de abri-lo aos outros, aprendeu sobre o senso de interdependência e ligação de toda a criação, no nível da alma adquirindo consciência mais aguçada sobre o significado do respeito e a aceitação de todos. A evolução do trabalho desta autora parte do foco intelectual e cognitivo para outro mais intuitivo que integra o conhecimento do coração, alma com o conhecimento racional se conectando com outros níveis emocional, espiritual, para além do nível intelectual.

Pois bem, nada mais revela Kay Pranis (2012) do que o trato das questões emocionais e dos sentimentos, avançando inclusive para o terreno da alma, do espírito como meios através dos quais vive o cotidiano da prática restaurativa. Portanto, este modelo pautado no bom senso como critério de encaminhamento é justamente o terreno para onde a humanidade se desloca resgatando práticas altruístas de respeito, solidariedade e colaboração.

É relevante dizer que a justiça restaurativa de fato e de direito é um novo caminho que se descortina à frente da humanidade, seja como resposta ao sistema jurídico tradicional há muito falido, seja como um novo modelo de resposta ao crime, mas, sobretudo, como uma proposta de olhar para as relações sociais a partir de um novo prisma, da vítima que não por isso descuida do autor do delito. Propõe em sua lógica dialógica, consensuada, altruísta, humanista o resgate da humanidade, do respeito e da esperança perdida em meio ao caos da violência, da indiferença, do rancor, da mágoa, da brutalidade das relações sociais. A justiça restaurativa, portanto, é a possibilidade concreta, possível e desejável para a contemporaneidade.

\section{Considerações finais}

Decorridos dezoito anos da Lei n 9.099/95, é importante reconhecer os problemas que cercam os Juizados Especiais Criminais, principalmente diante do discurso oficial de criação de uma justiça baseada no consenso nos cabe perguntar: o que está sendo conciliado, quem é o/a conciliador/a, como e quem está conciliando. Sua instalação deflagrou importantes inquietações quanto às questões conflituais que encerra que não podem ser deixadas de lado, pois forçam uma reflexão interdisciplinar e despertam agentes sociais e jurídicos para a preocupação com uma 
práxis resolutiva em tema de procedimentos judiciais e, o que é importantíssimo, contingenciou a organização da sociedade e do Estado para a aplicação de alternativas ao processo penal e à carceirização.

Todavia, enquanto em diversos países, os centros de justiça informal funcionam para remover do sistema casos considerados inúteis ou menores, no Brasil, os Juizados Especiais Criminais, ao invés de retirar do sistema formal os casos considerados de menor potencial ofensivo, incluiu esses no sistema, através de mecanismos informalizantes para o seu ingresso e processamento (SELVA E BOHM, 1987). A dispensa da realização do inquérito policial para os delitos de competência dos Juizados Especiais Criminais diminui a prerrogativa das autoridades policiais de selecionar os casos considerados mais "relevantes", que resultava no arquivamento da grande maioria dos pequenos delitos. Numa espécie de recriminalização, esses delitos foram incorporados ao sistema judicial, substituindo o/a delegado/a pelo/a juiz/a no exercício da função de mediação. O problema é que a estrutura judiciária não foi adequada para o recebimento dessa nova demanda que passou a representar quase $80 \%$ do movimento processual penal.

É, contudo, preciso reconhecer os aspectos emancipatórios que fazem parte do processo de informalização da justiça no caso brasileiro. No entanto, são justamente essas características as mais facilmente relegadas quando da implementação prática das medidas informalizantes, sendo reforçadas pompas formalistas e autoritárias. Claro que tendências históricas e atuais apontam para a ideia de que formalidades criam barreiras, mas também proporcionam um espaço no qual é possível proteger os setores socialmente desfavorecidos, enquanto que procedimentos informais são mais facilmente manipuláveis. Isto sugere que a efetivação de direitos através de procedimentos informais somente pode ser bem-sucedida se forem ultrapassadas as limitações inerentes à falta de apoio jurídico àqueles que pretendem exercer estes direitos. Portanto, um extraordinário esforço será necessário para conduzir o movimento de informalização procedimental da justiça em uma direção favorável. Os resultados deste esforço vão ter um significativo impacto sobre a vida cotidiana das pessoas comuns.

Os Juizados Especiais Criminais, tendo surgido sob a ideologia da conciliação e da dispersão para desafogar o judiciário, acabaram abrindo as portas da justiça penal a uma conflitualidade antes abafada nas delegacias, e para a qual o Estado é chamado a exercer um papel de mediador, mais do que punitivo. Nesse sentido, atuam muito mais como uma justiça complementar do que alternativa, pois tutela situações que antes sequer iriam aos tribunais. Entretanto, ainda cria-se uma lógica de mimetização dos tribunais, evitando-se processos de informalização que poderiam trazer inclusive celeridade. De fato, em alguns casos o que vemos é uma justiça “de segunda” voltada para os pobres. 
Para uma efetiva mudança no padrão de litigiosidade será necessária a criação de uma nova cultura judiciária pautadas na justiça restaurativa, que não veja os tribunais como fonte exclusiva de resolução de conflitos, e uma política judiciária que construa um sistema integrado para gerir de forma racional e diferenciada o volume da procura, apostando em outros mecanismos de resolução de conflitos, como a escola, o centro comunitário, a família, as valorosas experiências de justiça restaurativa. Também é necessária a criação de novos modelos de avaliação de desempenho que envolva toda a sociedade, permitindo constantes melhorias e a construção de um caminho para onde os tribunais judiciais sejam um serviço público de justiça de qualidade, cuja ratio seja, em primeiro lugar, a promoção e defesa dos direitos dos/as cidadãos/ãs. Neste contexto a justiça restaurativa é um caminho, uma possibilidade.

\section{Referências bibliográficas}

ASCENSÃO, José de Oliveira. O Direito - Introdução e Teoria Geral - Uma Perspectiva Luso-Brasileira. Rio de Janeiro: Renovar, 1994.

ANDRADE, Vera Regina Pereira de. Violência Sexual e sistema penal: proteção ou duplicação da vitimação feminina? Revista Sequência. No 33. Florianópolis: UFSC, dez/1996. ARAÚJO, Letícia Franco de. Violência contra a mulher: a ineficácia da justiça penal consensuada. Campinas: CS; São Paulo: Lex, 2003.

FILHO, Petrônio Calmon. O conflito e os meios de sua solução. In: DIDIER JR., Fredie e JORDÃO, Eduardo (org.). Teoria do Processo: Panorama internacional. PODIUM: Salvador, 2008

BRAITHWHITE, John. A future where punishment is marginalized: realist or utopian?” UCLA Law Review, volume 46, nota 16, p. 1743, 1999.

FABENI, Lorena Santiago. A justiça restaurativa pede passagem. In: Direitos Humanos e sua Efetivação na Era da Transnacionalidade - Debate Luso-Brasileiro. Coordenadores: Mario Ferreira Monte e Paulo de Tarso Brandão. Ed. Juruá. 2012.

FREITAG, Bárbara; ROUANET, Sergio. Habermas. São Paulo: Ática, 1980.

JACCOULD, Mylène. Princípios, Tendências E Procedimentos Que Cercam A Justiça Restaurativa. In: Bastos, Márcio Thomaz; Lopes, Carlos e Renault, Sérgio Rabello Tamm (Orgs.). Justiça Restaurativa: Coletânea de Artigos. Brasilia: MJ e PNUD, 2005. Disponível em: www.justica21.org.br/interno.php?ativo=BIBLIOTECA. Acesso em 04 out 2012 
HABERMAS, Jurgen. La necessidad de Revisión de la Izquierda. Madrid: Tecnos, 1996. p 163-209.

HERMANN, Leda Maria. Violência doméstica e os juizados especiais criminais: a dor que a lei esqueceu. 2 ed. Campinas: Servanda, 2004.

PEDROSO, João. A justiça em Portugal entre a(s) crise(s) e a(s) oportunidade(s) Contributo para a construção de um novo paradigma de política pública de justiça. Portugal: Scientia Iuridica, TOMO LV(2006), N. 306 - Abril/Junho.

PINTO, Renato Sócrates Gomes. Justiça Restaurativa - Um novo caminho? Disponível em http://www.justica21.org.br/webcontrol/upl/bib 357.pdf. Acesso em 11 maio 2012.

PRANIS, Kay. Justiça Restaurativa: Revitalizando a Democracia e Ensinando a Empatia. IN: SLAKMON, Catherine; MACHADO, Maíra Rocha; BOT'TINI, Pierpaolo Cruz (Orgs.). Novas Direções na Governança da Justiça e da Segurança. Brasília-DF: Ministério da Justiça, 2006. Acesso em 04 dez. 2012

RODRIGUES, Anabela Miranda. Celeridade no Processo penal - uma visão do direito comparado. IN: Revista portuguesa de Ciência Criminal, ano 8, fasc.2, abril-junho 1998. Coimbra Editora. P. 233-250.

SELVA, Lance e BOHM, Robert (1987). A critical examination of the informalism experiment in the administration of justice Crime and Social Justice, 29: 43-57.

SANTOS, Boaventura de Sousa. Os Tribunais nas sociedades contemporâneas: o caso português. Cap. 1 (págs. 19 a 56). Coimbra: Afrontamento, 1996.

WUNDERLICH, Alexandre. A vítima no processo penal (impressões sobre o fracasso da Lei $\mathrm{n}^{\circ}$ 9.099/95). IN: WUNDERLICH, Alexandre; CARVALHO, Salo de. Novos Diálogos sobre os Juizados Especiais Criminais. RJ: Lumen Juris, 2005. 